Regional and Business Studies (2020) Vol 12 No 2, 93-107

Szent István University Kaposvár Campus, Faculty of Economic Science, Kaposvár doi: $10.33568 /$ rbs. 2523

\title{
Application of a Simulation Model in an Agricultural Vocational School Through EXAMPLES From the Livestock SeCtor
}

\author{
Viktória Horváthné Petrás \\ Szent István University Kaposvár Campus, H-7400 Kaposvár, Guba Sándor u.40
}

\begin{abstract}
In today's education system, it is possible to prepare a skilled workforce within the framework of public education, higher education and vocational training outside the school system. One of them young people need to be prepared for activities that require adaptability and perseverance. In contrast, there has been a level of development in agriculture that neither teacher training nor vocational training can keep up with, as a result of which it is not possible to teach in the same wayas before. Significant renewal is needed in secondary agricultural education. One of the areas of this is the renewal of technical and IT training, the improvement of the standard of practical education following technological innovations. Numerous researches show that educators need to breakaway from the "outdated" methods used so far, more emphasis should be placed on motivation and practice, as these graduates will ultimately be business leaders who will coordinate the work of their professionals (Berke and Kömüves, 2016; Kömüves, Berke and Póra, 2016). It is therefore important and necessary to apply and put into practice the ever-expanding innovative teaching methods. As an innovative pedagogical method, I examined the possibilities of applying the simulation model I created, as this model can point to interdisciplinary relationships that enable students to study an economic process in a broader, more complex light by broadening their knowledge and reflectiveness.
\end{abstract} Keywords: agricultural, education, junior high school, innovation, simulation, model

\section{INTRODUCTION}

In 2005, Andor drew the attention of educators to the fact that many educators do not know about the innovative methodological solutions needed for differentiated development, they do not even recognize the professional problem and often see a disciplinary issue which they should solve with pedagogical tools.

Demonstrating this idea, Lakatosné Török (2010) examined - what the reason may be why educators are reluctant to switch from traditional methods to innovative methods. The counter-arguments included the lack of time and resources, which, in the opinion of researchers, shows that the majority of the interviewed educators are not really clear about the essence of the methods mentioned above.

Based on a number of other studies (Falus, 2001; Petriné Feyér, 2001; Radnóti, 2006; Szücs, 2018) we can say that teachers in schools are reluctant to employ 
methods that disrupt the normal, traditional „order” to some extent. For 45-minute lessons, this thinking is particularly striking. This also explains the fact that the various methods, which can be called novel, even if they occur in schools, are still more in the practice of only one teacher (Radnóti, 2009).

However, it should be emphasized that literature increasingly reports on innovation efforts, changed trends, and even paradigm shifts in educational methods. According to these literature sources, traditional roles in education have changed, the role of the teacher facilitator has come to the fore, just like teamwork and cooperation, we can meet more and more innovative aspirations, mega renewal intentions are becoming more and more pronounced (Czakó, 2017).

In today's educational system, more emphasis is placed on theoretical education. Traditional Central European education systems primarily provide lexical knowledge that is easily and quickly available on the Internet, and knowledge of the facts alone does not provide as much competitive advantage as in the past (Schmuck, 2018). In the labor market, however, there is a growing need to train practice-oriented professionals who can make professional decisions quickly and efficiently in everyday life. Simulation models can also be used appropriately in agricultural education to develop all these skills.

It is also important to emphasize that the changed economic and technological environment requires the development of new modern educational curricula. This is also theopinion of Dailey and his research team (2001), who emphasize that technological advances have made it timely to update curricula, integrate several other disciplines to develop effective teaching-learning strategies, such as precision agriculture, where knowledge complexity is required, with the simultaneous application of several disciplines. Challenges need to be addressed in the short term as this can be a barrier to further development. Technology innovations, which involve the day-to-day use of IT tools, are important. The other important area, in my opinion, is innovation. In the rapidly evolving world of technology, scientific and technical "literacy" is becoming an important part of studies. Most schools have found that nowadays retaining students, or even avoiding school closure, also depends on the ability to innovate (Bartha, 2007).

Innovation lies in the use ofnew pedagogical methods that are different from traditional frontal education and differ from existing teaching practices. The IT tools that have always stimulated the development of the information society must not be left out of this quest for renewal. The emergence and educational application of technical tool miracles cannot yet be called innovative in pedagogical practice. School innovation lies primarily in the free access to information, which cannot be limited to IT or just computers, or even the use of the Internet. It includes everything that the teacher or student uses during the teaching-learning process. In this group of methods, thanks to learner-centered activities, students can be part of knowledge building. Thanks to next-generation methods, learners not only gather information using a computer, but use the information gathered to create new content. In this process, they become active knowledge creators instead of actors, students and teachers, information consumers (Filep, 2017). 
In the teaching of agricultural sciences, we must strive to capture reality as realistically as possible, in order to present the various biological processes as accurately as possible. If this is not possible, we can use other tools or methods to illustrate the phenomenon, such as modelling, in which innovative tools can provide significant help.

In the case of animal husbandry process models, the essence of the simulation is to monitor the development of the animals by selected time units or days. According to the context of the model, the characteristics of the changes (reproduction, weight gain, feed use, etc.) during the period are calculated using the initial data. The results of the process are summarized at the end of the simulation. Animal husbandry simulation usually covers the whole process and often consists of several, successive repetitions (Csáki, 1976).

In collaboration with the Department of Feeding of the University of Kaposvár and the Feeding Group of the University of Wageningen, a dynamic - mechanistic model has been developed to estimate the performance of piglets with a live weight of 20-105 kg (Halas et al., 2004). The developed model is suitable for estimating the growth rate and performance of animals, even within wide body weight limits. However, a qualitative estimate can also be made if the body fat content or the protein I fat ratio is taken into account as a qualitative factor in the calculations, so that the model can be used to determine the optimal nutrient content of the feed mixes fed in each feeding phase, necessary to achieve growth or protein incorporation. Using the model, the most optimal feeding strategy for the herd can be developed, and feed manufacturers can also benefit from the development of a new feed or a new feeding system that better meets the needs of the animals (Halas and Babinszky, 2007).

So far, attempts have been made to solve the tasks of organizing and planning the livestock sectors with various methods, such as calculation methods, but the further development of all of these is moving towards simulation methods, which can be used to examine the operational characteristics of biological systems. This stateof-the-art operations research procedure makes it possible to examine the complex impact mechanism and correlation of the ecological, economic and agrotechnical factors influencing the income of the given sector, and it can also provide the analysis of the separate, partial efficiency of each factor. Balogh (2017), in his doctoral thesis "Economic Analysis of Pig Meat Production and Consumption", he developed a simulation model of a pig farm, taking into account the farm values of the fattening raw material production farms, in which the profitability indicators of sow keeping and pig farming can be forecast by incorporating various risk factors. The model can be applied to any pig farm, providing an opportunity for economic analysis of herds with different constitutions. In his study, based on the results of the model used, he showed that among the production (natural) factors, the fluctuation of the farrowing average and pig feed consumption is the most significant for farm profitability, value. As a result of the changes in the economic and environmental factors, there was a growing need to apply the results obtained during the simulations in practice as a decision - support system. Examples are CLIMAK, CROP or the $4 \mathrm{M}$ method, which are used to increase the high efficiency of field crop production. 


\section{METHODS}

The parameters of the simulation model I made were provided by the data of a livestock farm in Somogy county. The farm has been operating since 1999, with nearly 65 sows. Their work also includes breeding and fattening, so they deal with nearly 1800-2000 animals per year showing conspicuous differences. Since the main goal of pig breeding is meat production, for the economic production of which it is essential to ensure the right number and quality of reproduction (Soltész, 2015). So I started my research by collecting the breeding indicators of the farm, summarizing the data of the last three years from January 2018. The last data set was recorded in March 2020. During the documentation, 433 pups were recorded, in which we covered the number of piglets born alive and still during calving, male and female, and the number of piglets at the time of selection in the proportion of sex. The recording of the data of the pups was followed by the systematization of the data sets, which were individually guided per sow, into the MS Excel program.

After processing the data and statistical analyzes describing the distributions, the simulation method was developed, based on the elements of the Monte Carlo method (MC method for short). The method is essentially based on random sampling, with which we can estimate definite integrals for a large number of samples. In the model to be analyzed, I recorded the influencing variables and their time intervals, probability distributions, and the relationships between the variables. I generated real-value random numbers (1000 pieces) between zero and one - presumably with an even distribution, which I ran with a computer with 1000 experimental numbers, so I got an expected value for the result variable to be determined.

I narrowed the preparation of the model to the total number of piglets born, the number of stillborn piglets, and the number of animals that died before the selection. During the simulation, by changing the variables in the simulation data set from 0 to 1 , using the "HA" function in the simulation, both the distribution function and the frequency diagram elements change, showing how the simulation we give affects the elements of reality. In the simulation result, changes affecting the entire economic process can be "predicted", which can form the basis of certain economic calculations, so either revenue-income relations can be forecast in advance, or it is also excellent for ordering feed base or feed raw material.

\section{RESULTS}

I present the simulation through the example of pre-election death. In Figure 1, a state approaching the baseline was recorded. It is clear from the data that there were 129 cases in the original data set that no deaths occurred until the selection. The value I gave in the simulation assumes 139 cases that reflect the same state. The result of the simulation model in this situation is 151 which can happen with such a number of cases. 


\section{Figure 1}

\section{Frequency chart of lost before before veaning}

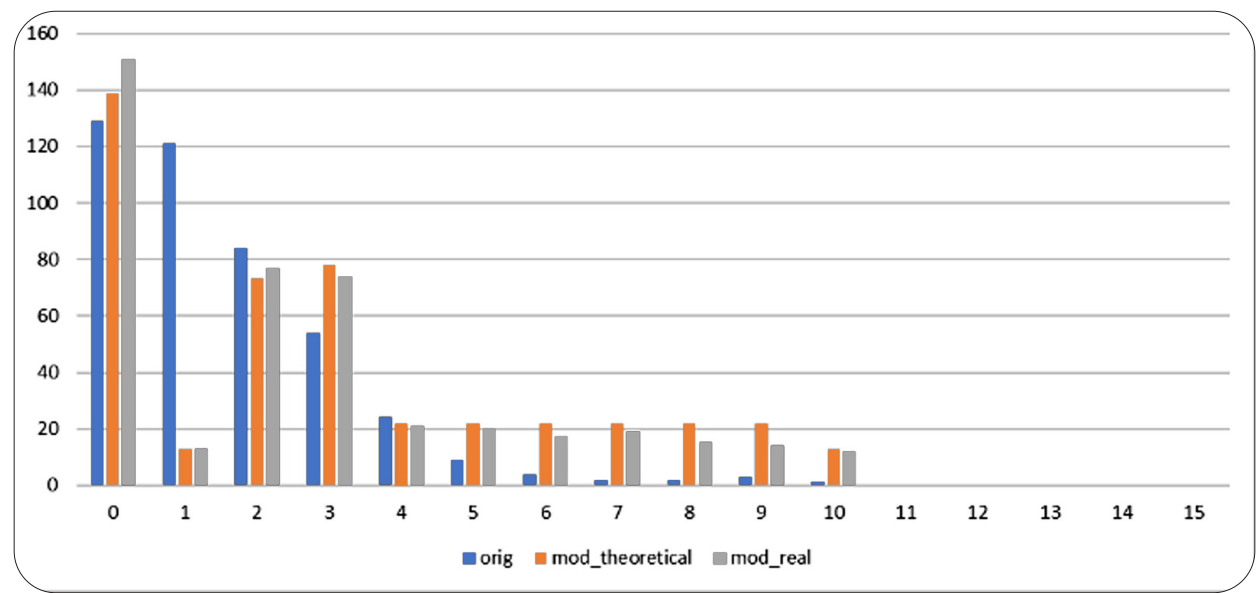

In Figure 2 we can observe the probability values belonging to the first state, that is, the probability of the realization of the state we assume will occur.

\section{Figure 2}

\section{Distribution of lost before veaning}

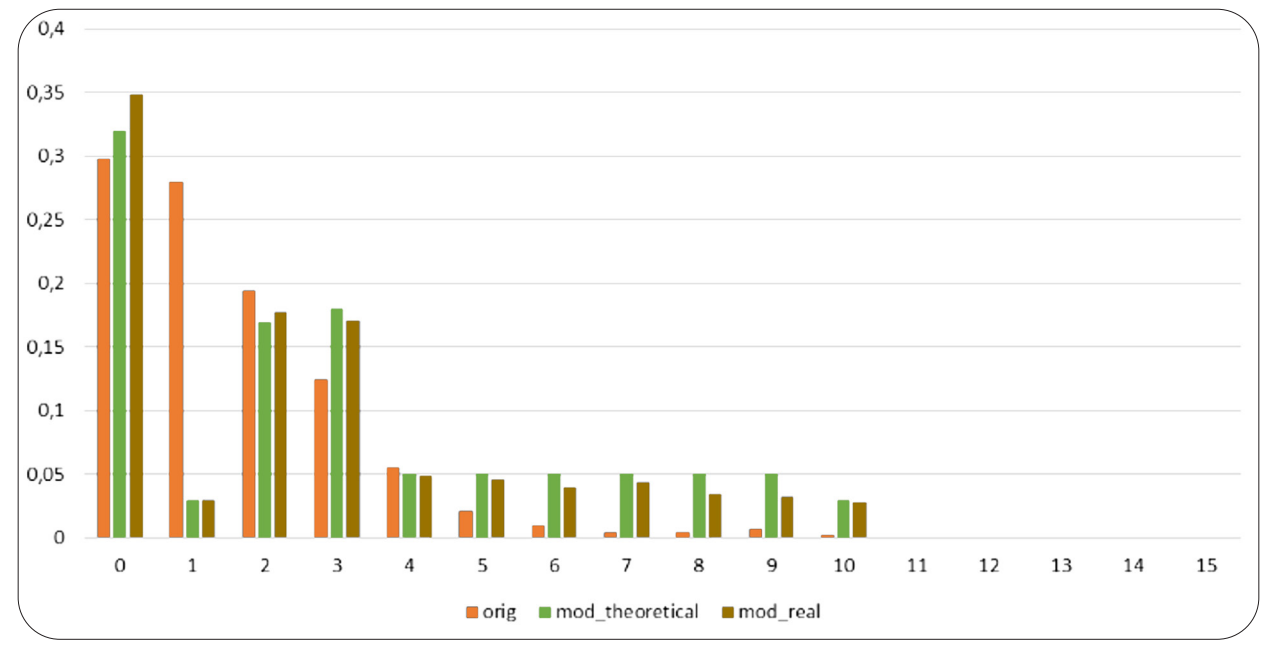

From the data in the graph, it can be seen that according to the original data series, the case of non-deaths until the selection occurred in $30 \%$. As a consequence of the values changed during the simulation, we can expect the same condition to occur in $32 \%$. During the continuous simulation, we generated a case in the probability variables in which the option of non-mortality was chosen in $32 \%$, the number of cases in $3 \%$, the number of two cases in $17 \%$, the death of three animals in $18 \%$, the other 
cases were determined with equal percentage probability. The simulation diagram is shown in Figure 3.

Figure 3

\section{Distribution of lost before veaning after the simulation}

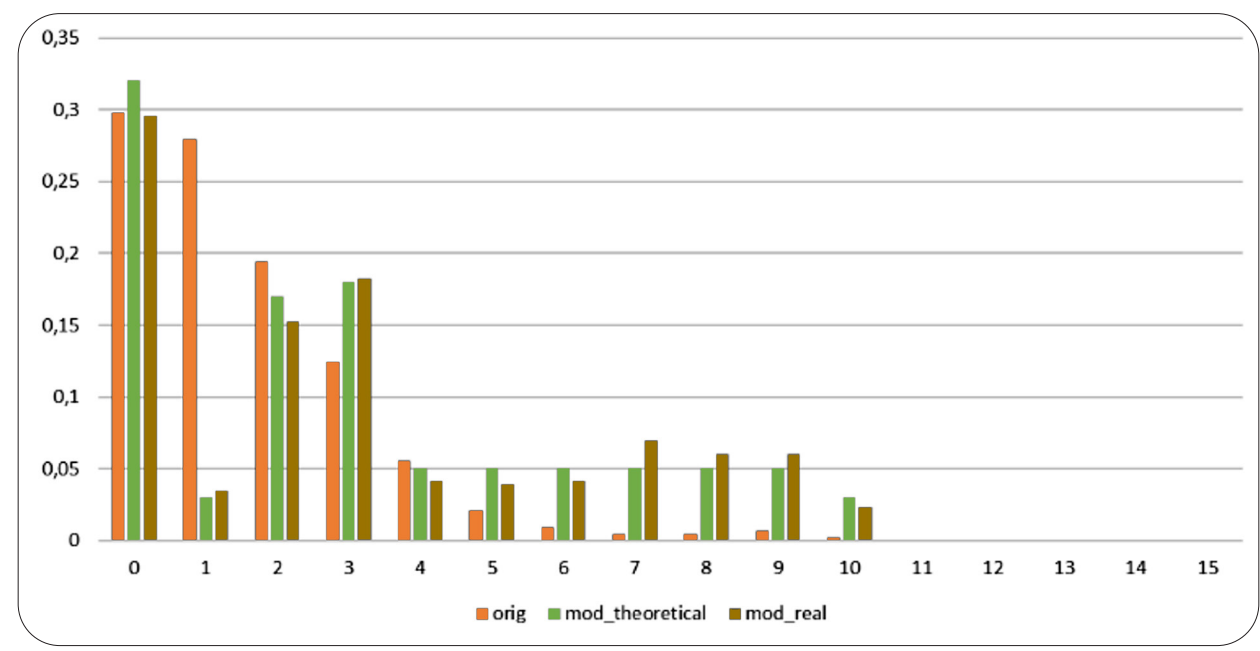

With the help of the simulation, after determining the probability variables, it can be seen from the mortality frequency data that the original (129) cases, in which no death occurred during the simulation (due to the change we gave), increased to 139 cases. The result of the simulation (the case simulated by the model) changed to 113 times at which no death occurred until the selection. The results are shown in Figure 4.

Figure 4

Frequency chart of lost before veaning after the simulation

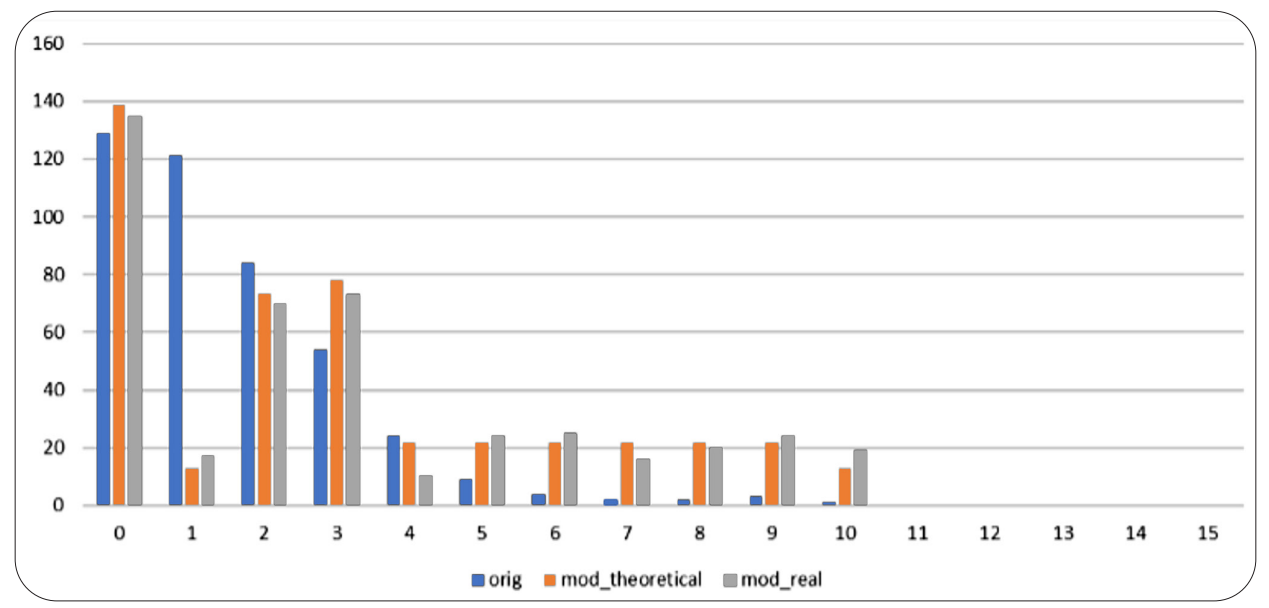


Performing economic calculations, the other case numbers must take into consideration in order to achieve values as close to reality as possible. The simulation model described above was presented at Zsigmond Móricz Agricultural Technical School in Kaposvár in November 2020, in the classes I also taught, the selection of which was based on the training courses at the school. Of the $11^{\text {th }}$ farmer grades 24 , those in vocational school training 29 , and 21 technicians participated in the research. The model was presented via an online system, in view of the Covid-19 situation, in which, first of all, I tried to collect and organize the students' previous knowledge with the help of a PowerPoint presentation in a traditional system, thoroughness of their knowledge. In the introductory phase, I used the economic indicators of the sector to present the world economic situation of pig breeding, the difficulties in Hungary and the quality of production. The introduction, the questioning of the basic professional concepts took one lesson, i.e. 45 minutes, and then the next time the simulation model already sent via the Internet was presented. The characteristics of the students are shown in Table 1.

\section{Table 1}

Description of the students participating in the simulation model

\begin{tabular}{|l|c|c|c|}
\hline \multicolumn{1}{|c|}{ Aspect / classes } & $\mathbf{1 1}^{\text {th }} /$ Farmer & $\begin{array}{c}\mathbf{1 1}^{\text {th }} / \text { Vocational } \\
\text { high school }\end{array}$ & $\begin{array}{c}\mathbf{1 3}^{\text {th }} / \text { Agricultural } \\
\text { technical school }\end{array}$ \\
\hline Number of study participants & 24 & 29 & 21 \\
\hline Boy & 24 & 15 & 18 \\
\hline Girl & 0 & 14 & 3 \\
\hline Number of day-pupil & 19 & 21 & 10 \\
\hline $\begin{array}{l}\text { Summary of the class based on } \\
\text { study results }\end{array}$ & average & above average/ good & average/ medium \\
\hline
\end{tabular}

When applying the model, as a first step, I focused on the interpretation of the data collected and processed in the Excel spreadsheet, in which we looked at the number of live and stillborn piglets during the filing compared to the number of weaners, reflecting 433 calving data.

The presentation of the model and the performance of some of the economic calculations that formed the basis of the data generated by the model again took a lesson, during which the students could also try out the model, which they experienced almost as a "game". After the presentation of the model, I processed the effectiveness of the lessons and the model among the students in all three class types with the help of a questionnaire.

After processing the responses to the questionnaire, I obtained the following results. My questions focused primarily on the extent and effectiveness of our students' ability to create and analyze an Excel spreadsheet to assist in the processing and interpretation of data. The results are shown in Figure 5 and Figure 6. 
Figure 5

\section{Difficulties in interpreting tables and graphs}

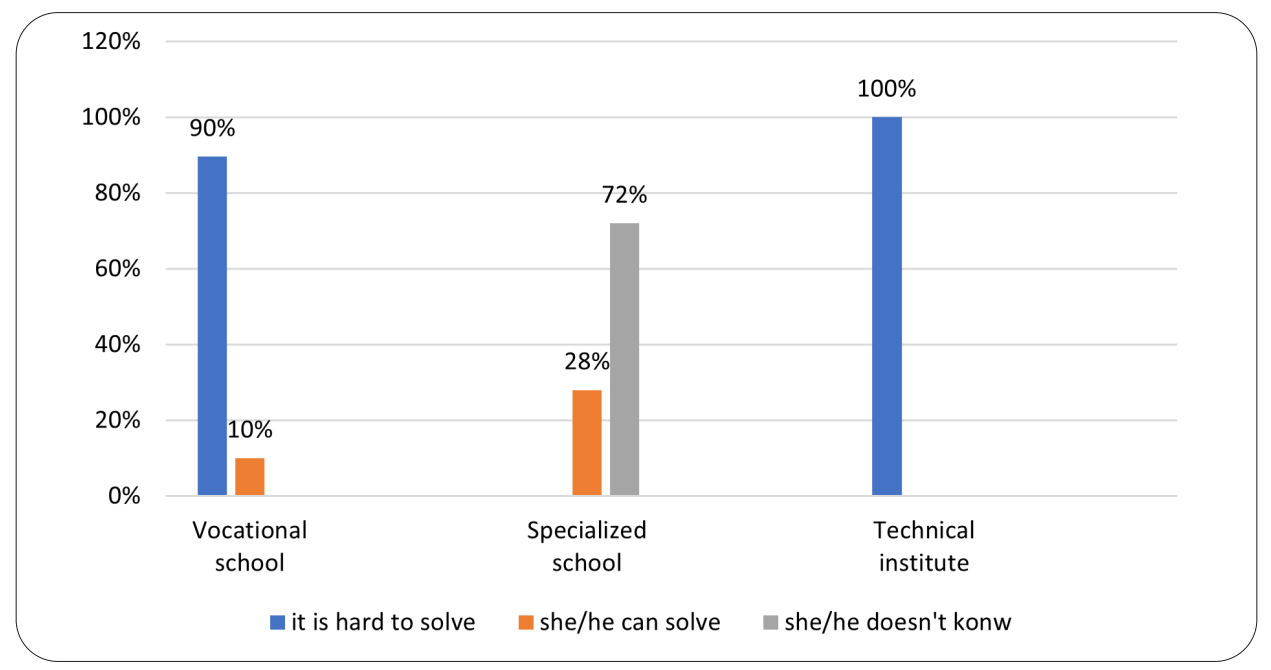

Figure 6

Interpretation of the data in the table

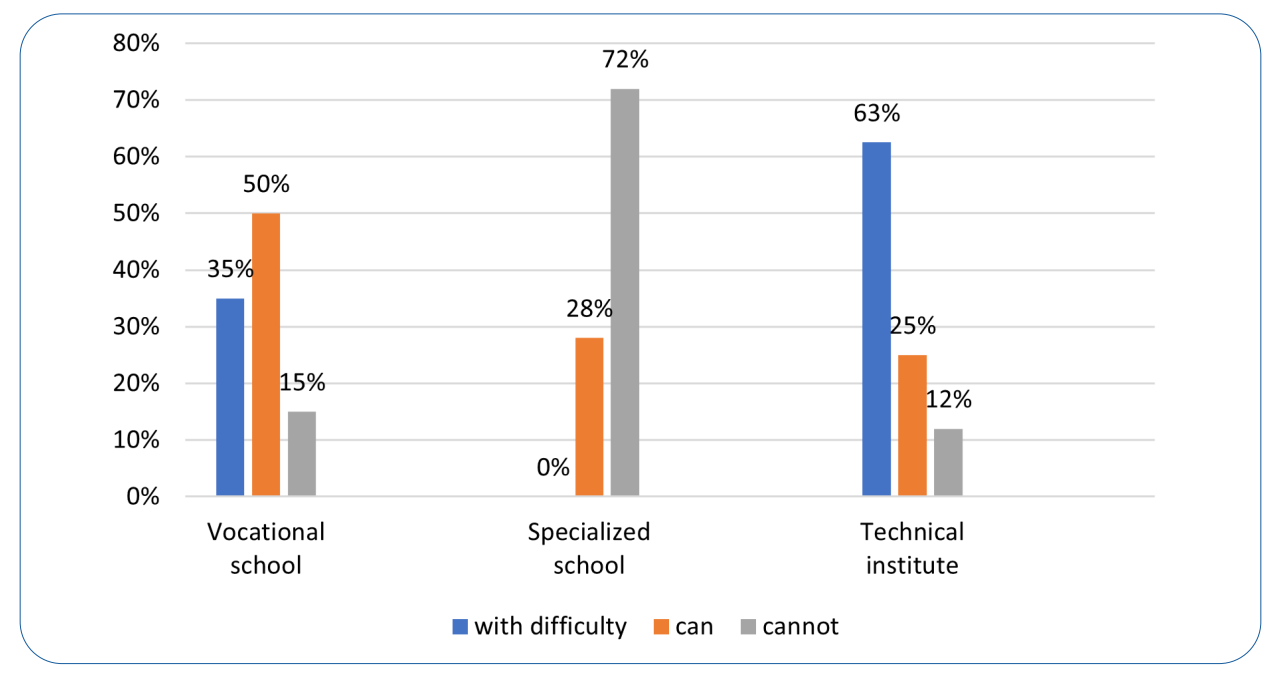

My results differ significantly in the three forms of training. Higher quality students who have already graduated from technical training are able to use the computer $100 \%$ for the right purpose, while among our students in vocational training, the use of an independent computer for this purpose is only marginally possible. The majority of vocational high school students are able to use computer programs independently and without help (90\%). 
The results of the graph illustrate well that our vocational school students are at a significant disadvantage in this area as well. An interesting result is that students in technical training who excel in creating spreadsheets, have difficulty in reading and interpreting the results. Overall, there is an equal distribution of vocational school students who can interpret the graphs and figures, as well as those of our students who have difficulty.

The inclusion of this data was necessary because the model was developed and processed in Excel, and the changes had to be tracked on graphs. If the interpretation of the data is difficult, it becomes impossible for the user to evaluate the results of the simulation model.

My results were as expected, so I asked at the beginning of the questionnaire how important they think the importance of school IT education was and whether they wanted to gain more IT knowledge. The results are illustrated in Figure 7.

Figure 7

\section{To what extent is there a need to expand IT knowledge?}

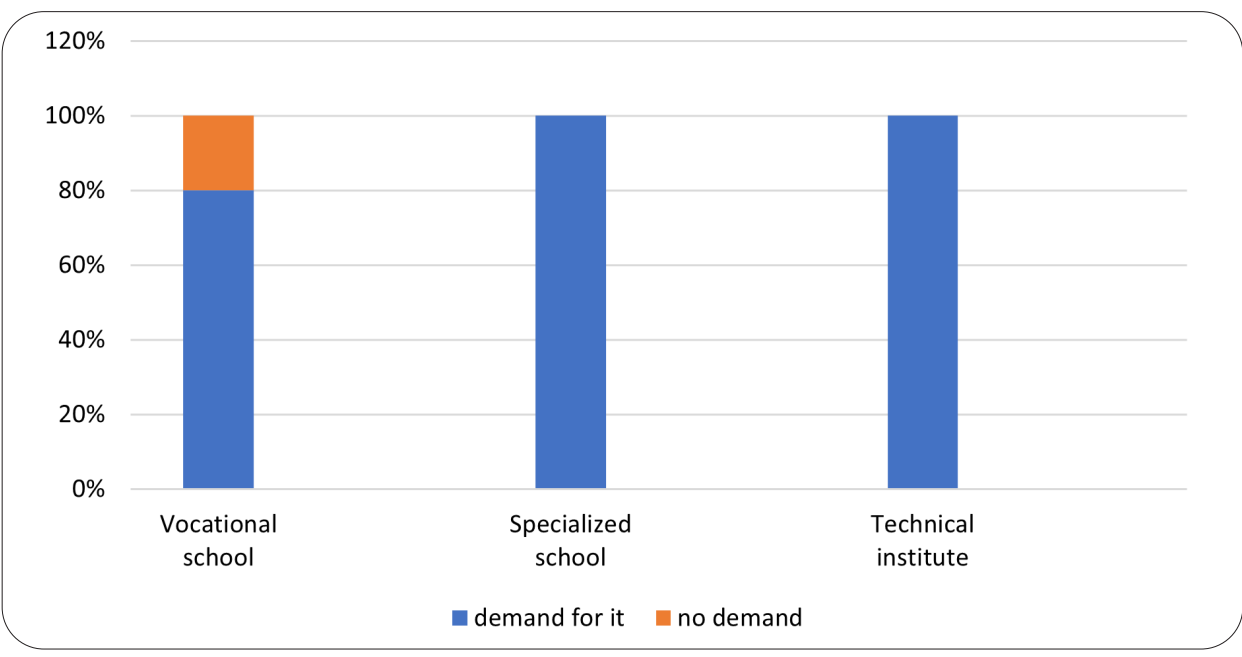

It is commendable on the part of the students that, based on the results of the first two questions, they see the lack of their knowledge about IT and feel the need to broaden their studies. During the lessons the students said that although they had IT lessons, they did not have enough knowledge, they did not have enough time to deepen it enough, and they only used the opportunities provided by the computer for their own purposes, including computer games and social networking. My questions then focused on the extent to which the material related to the curriculum I have described, which was essential for understanding further economic conditions. The results obtained are shown in Figure 8.

During the preparation for the lesson it was a primary point, besides neglecting the traditional methods, to implement the innovative lecture principally based on the ICT devices. Unfortunately, due to the changing circumstances (high school and university lectures held online), the background information which was needed for 
the understanding of the sumilation method could only be revised on lectures held with the help of traditional methods and frontal class work. Economic concepts, lexical knowledge, analysis, and relationships are difficult to teach. Students' interest in the curriculum is low. The effectiveness of the information processing showed an unexpected picture. The results obtained are shown in Figure 9.

\section{Figure 8}

\section{Acceptance of "background information" among students to process the new curriculum}

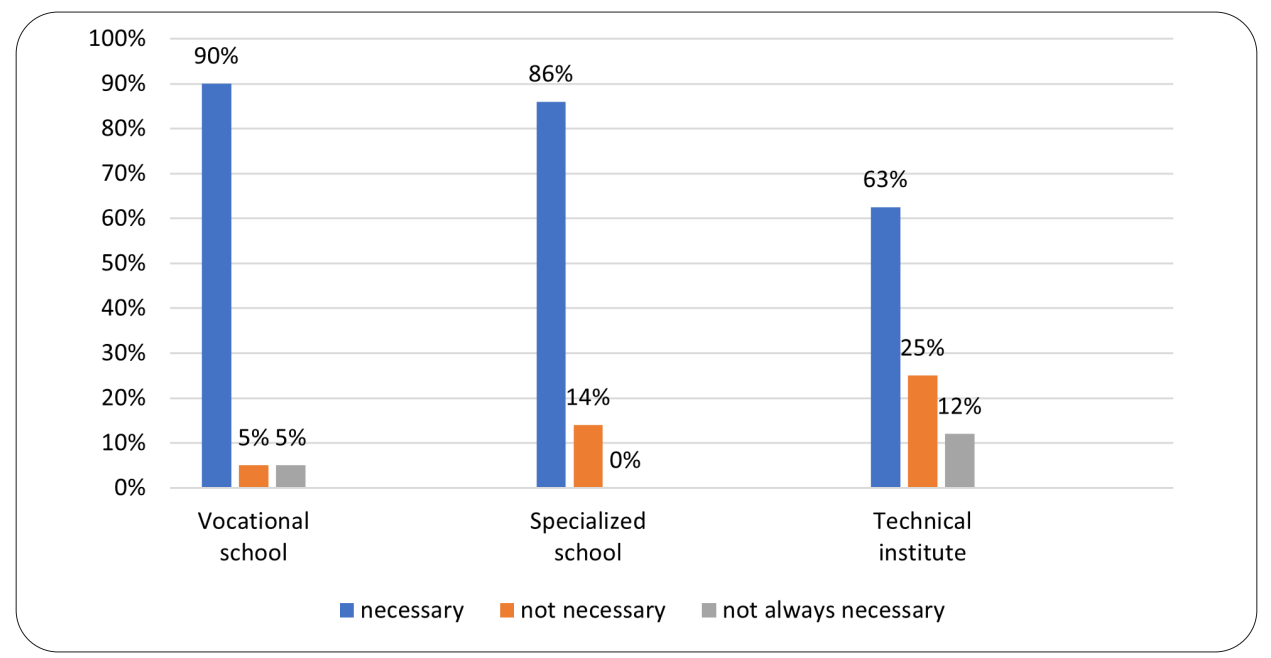

Figure 9

\section{The distinctness of economic analysis}

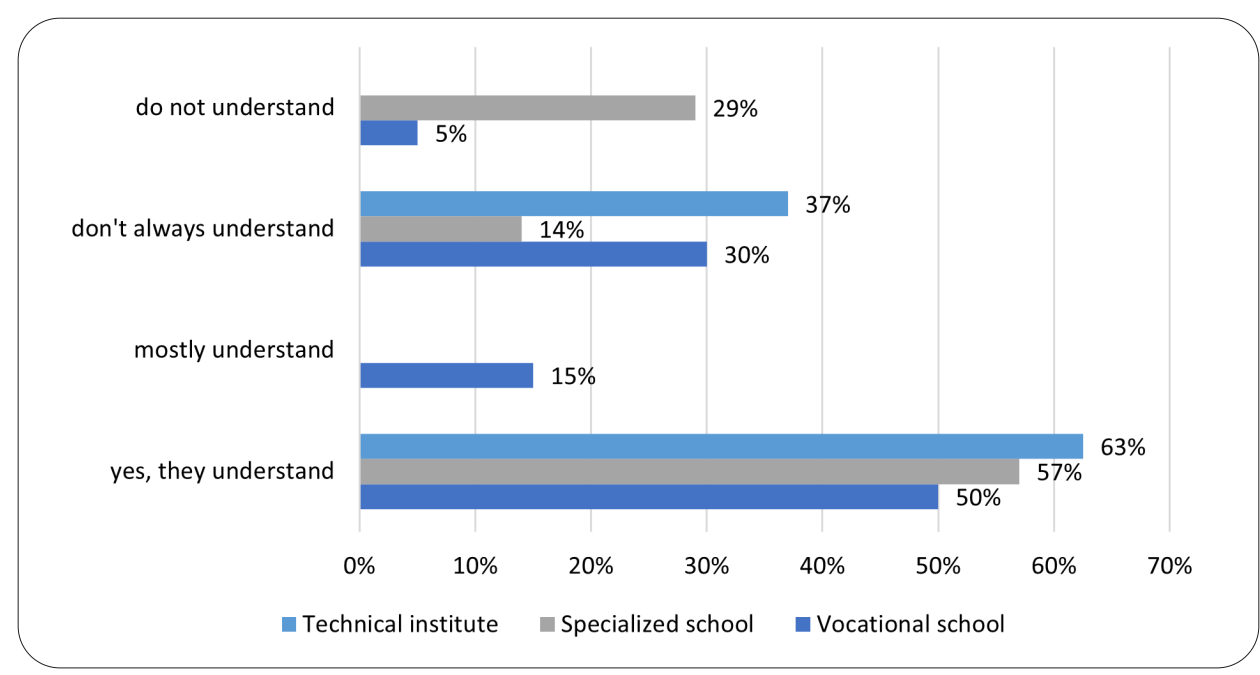


As expected, most people understand the economic context and analysis in the technical class, but it is surprising that the category "does not always understand" compared to the three forms of training - was most marked in this class. Half of the vocational high school students clearly stated that they understood the connections and analyzes and only 5\% could find that they could not interpret what was said on the topic. Surprisingly, more than half of vocational students are susceptible to this type of knowledge and only $14 \%$ of the students have difficulty in interpreting, given that students in this type of training performed below average on competence tests.

I also encountered difficulties in the clarity of the meaning of the basic concepts and the accuracy of their knowledge, but these differences could also be attributed to the differentiation of the teaching materials and subjects resulting from the training. $25 \%$ of students in vocational high school training, $14 \%$ of students in vocational school training and $13 \%$ of technicians had not encountered the basic concepts during their previous studies. Not all concepts were encountered by half of the vocational high school students, $45 \%$ of the participants in the vocational qualification and $37 \%$ of the technicians. Among the advantages of the simulation method, it is important to highlight the fact that students who did not understand or understood only to a lesser extent the meaning of the basic concepts, $35 \%$ of vocational high school students, $15 \%$ of vocational school students and $13 \%$ of technical school students gave the answer that they understood the concepts and contexts through simulation. The primary goal during the development of the simulation was to create a pedagogical method in which the students' thinking, understanding of economic concepts and contexts, their correct application could be developed or formed. In light of the results, the simulation model used in animal husbandry meets our requirements.

Questions about the novelty and usefulness of the method received positive feedback from almost all departments. The answers are given in Figure 10 and Figure 11.

\section{Figure 10}

\section{The extent to which the method is considered useful}

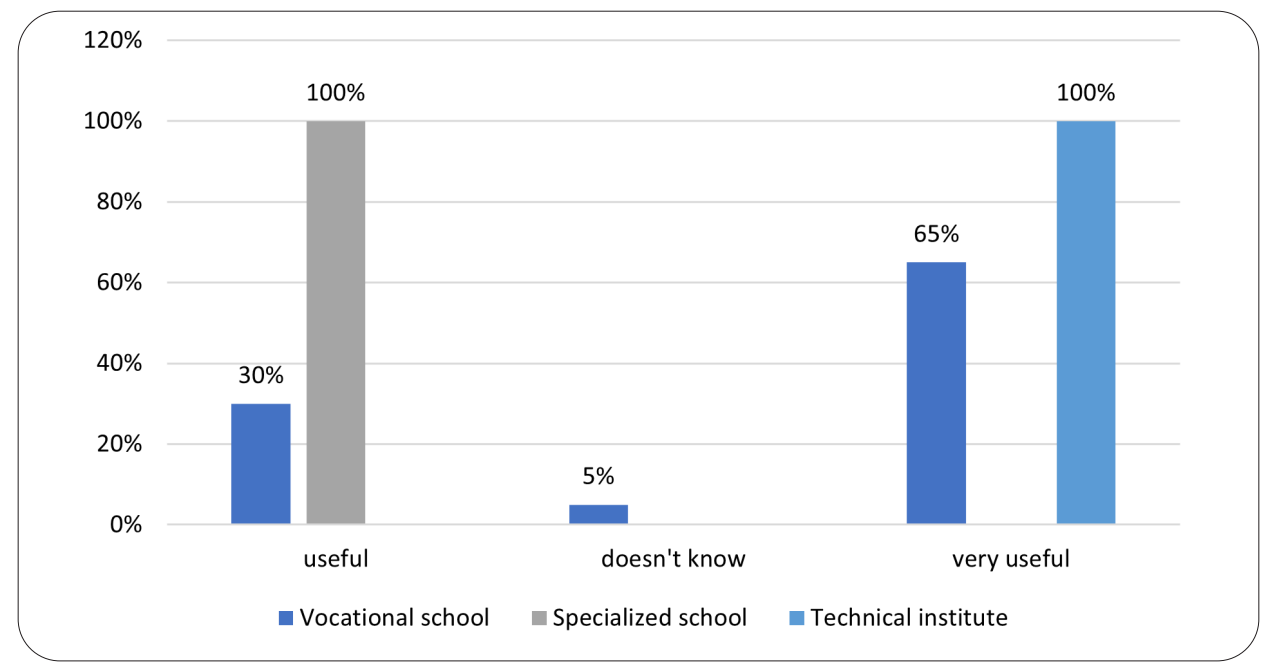


Useful and very useful answers were chosen by a significant majority of students in both the technical class and the vocational school class, while 5\% of students in vocational high school were unable to decide on the applicability of the model in everyday life based on what had been said. The novelty of the method I have described was marked as $100 \%$ innovative by our students, with the exception of the technician class, while three students of the classes mentioned had already encountered the method during their internships.

\section{Figure 11}

\section{To what extent do you find the lesson interesting?}

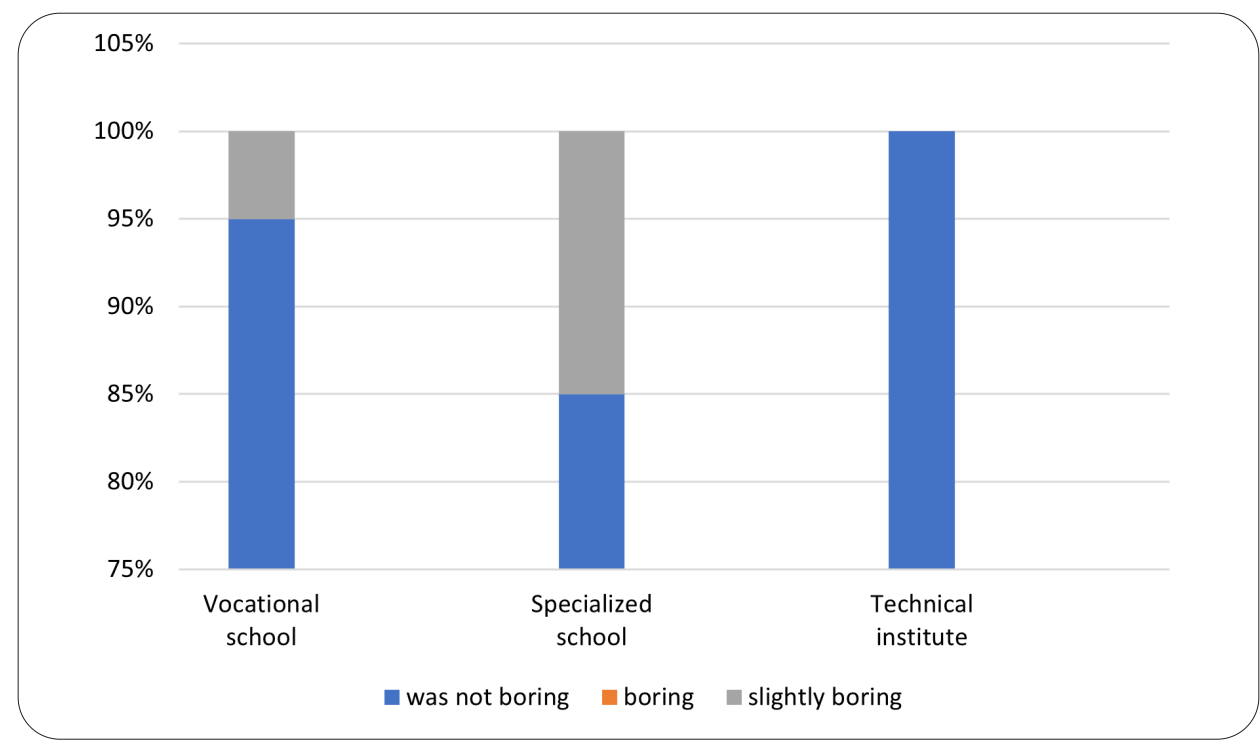

One of the very significant challenges for teachers in the spirit of the age is to raise the awareness of students during the processing of the curriculum, to maintain the motivation covering the whole lesson while observing the discipline necessary for successful work. So in the end, I asked our students to comment on the extent to which the lesson I compiled was interesting or boring for them. Analysing the answers, our students in the technical training consistently rated the lesson as interesting and effective, while among the other two students in the training there were those, whose parts seemed boring, but they also found the model interesting and effective. They were experienced in a theoretical, systematizing lesson processed with the method of frontal classroom work, but the lesson executed with the innovative method ended with positive experience for them as well. These answers also show clearly our initial assumption that traditional pedagogical methods are not sufficient to prepare students of the present age for exams. 


\section{DISCUSSION}

Thanks to the pace of development of the technology used in agricultural fields, following the agricultural operations getting more specified we have to pay attention to the individual needs of the branch when it comes to training an expert. The appearance of innovative technology challenges the pedagogues and educators again in fulfilling their work. It is important to mention the fact that the cognitive skills of pupils who attend agricultural education seem to be weaker, than their trade schooler or high schooler partners', therefore during their education pedagogues have to use unique methods during a succesful educator - preceptor process.

In our research we examined - as our innovative educational method - how our simulation models influence or ease the pedagogues in managing the learing process.

The model was published in the circles of technician learners, school leavers and $11^{\text {th }}$ graders of trade schoolers in Zsigmond Móricz Agricultural Trade School of Kaposvár.

The curriculum was presented in two parts, online, due to the Covid-19 situation. The students could get acquainted with the simulation model and the advantages of its use, after performing the mapping of preliminary knowledge and discussing the economic connections. After fnishing the lecture a questionnaire was sent to the pupils to measure the method's effectiveness. Pupils found the simulations efficient and interesting and in their feedback they expressed that mastering their previous studies, economic and proffesional notions and connections were then understandable thanks to the simulation method.

\section{CONCLUSIONS}

In the course of my research work, I formulated the following conclusions and suggestions:

- The use of simulation models also requires significant IT knowledge from teachers, and greater emphasis should be placed on introducing pedagogical methods based on ICT tools in the field of teacher training.

- The successful application of simulation models also requires a number of prior knowledge, the mapping of which, the preparation for the use of the model chosen by the teacher presents numerous additional tasks for the teacher, but overall has a positive effect on students' interdisciplinary and cognitive thinking.

- The circumstance influencing the success of the use of the method is that the simulation model can only be used with suitable infrastructure.

- Our research has clearly shown that by applying innovative pedagogical methods that have an experiential effect on students, it is possible to have more successful and productive lessons.

- Hungarian agriculture has also developed to such an extent that neither teacher training nor vocational training can keep pace with, and the result of which is that it is not possible to teach the same in the same way as before. Significant renewal is 
needed in secondary agricultural education. One of the areas of this is the renewal of technical and IT training, as well as the in-service training of specialist teachers, which is an essential condition for ensuring quality education.

\section{ACKNOWLEDGMENT}

The publication of this paper is supported by the EFOP-3.6.1-16-2016-00007." Intelligent Specialization Program at Kaposvár University" project.

\section{REFERENCES}

Dailey, A. L., Conroy, C. A., \& Shelley-Tolbert, C. A. (2001). Using Agricultural Education As The Context To Teach Life Skills. Journal of Agricultural Education, 42(1), 11-20. https://doi.org/10.5032/jae.2001.01011

Andor, M. (2005). Lépéskényszer: az extenzív fejlődés lehetőségeinek kimerülése az oktatásban. Iskolakultúra, 15(3), 57-70.

Balogh, P. (2017). Global and national economic importance of pig meat production. Acta Agraria Debreceniensis, (73), 13-20. https://doi.org/10.34101/actaag$\operatorname{rar} / 73 / 1620$

Bartha, I. (2007). Az innováció szükségessége az oktatásban, https://dea.lib.unideb.hu/ dea/bitstream/handle/2437/4328/innovaciocikk1.pdf, Retrived: 2020.06.05.

Berke, Sz., \& Kőműves, Zs. (2016). Satisfaction, motivation and personality types by sales leaders in SME sector: a pilot study In: Csata, A., Bíró, B.E., Fejér-Király, G., György, O., Kassay, J., Nagy, B., \& Tánczos, L.-J. (eds.), Challenges in the Carpathian Basin. Integration and modernization opportunities on the edges of Europe, $13^{\text {th }}$ Annual International Conference on Economics and Business (pp. 82-90). Cluj-Napoca, Romania: Editura Risoprint (ISBN:978-973-53-1855-0)

Csáki, Cs. (1976). Szimuláció alkalmazása a mezőgazdaságban. Budapest: Mezőgazdasági Kiadó.

Falus, I. (2001). A pedagógusok pedagógiája. Budapest : Nemzeti Tankönyvkiadó.

Filep, D.O. (2017). Innovatív módszerek szükségessége a természettudományos oktatásban, (Master's dissertation, University of Miskolc, Faculty of Arts) http:// midra.uni-miskolc.hu/document/27744/23380.pdf Retrived: 2020.06.05.

Czakó, Á., Győri, Á., Schmidt, L., \& Boros, I. (2017). Innovatív pedagógiai módszerek a szakmai oktatásban - A szakmai tanárok módszerei szociológiai megközelítésben Socio.hu, 1-21. https://doi.org/10.18030/socio.hu.2017.2.1

Halas, V., Dijkstra, J., Babinszky, L., Verstegen, M. W. A., \& Gerrits, W. J. J. (2004). Modelling of nutrient partitioning in growing pigs to predict their anatomical body composition. 1. Model description. British Journal of Nutrition, 92(4), 707-723. https://doi.org/10.1079/bjn20041237

Halas, V., Babinszky, L. (2007). Szimulációs modellek a sertéshústermelés prognosztizálására. Acta Agraria Kaposváriensis, 11 (2), 13-20. 
Kőműves, Zs., Berke, Sz., \& Póra, G. (2016). Survey on female managers In: Csata, A., Bíró, B.E., Fejér-Király, G., György, O., Kassay, J., Nagy, B., \& Tánczos, L.-J. (eds.), Challenges in the Carpathian Basin. Integration and modernization opportunities on the edges of Europe, $13^{\text {th }}$ Annual International Conference on Economics and Business (pp. 252-266). Cluj-Napoca, Romania Kolozsvár, Románia: Editura Risoprint (ISBN:978-973-53-1855-0)

Lakatosné Török, E. (2010). Informatikai kompetencia, oktatási stratégiák és módszerek pedagógiai innováció szolgálatában, (PhD thesis). www.edu.u-szeged.hu/ phd/downloads/lakatosne_torok_tezis_hu.pdf Retrived: 2020.06.05.

Petriné Feyér, J. (2001). A pedagógusok pedagógiája. Golnhofer E., Nahalka I. (eds.), Budapest: Nemzeti Tankönyvkiadó.

Radnóti, K. (2006). Hidak a tantárgyak között. Kerber Z. (ed.), Budapest: Országos Közoktatási Intézet. ISBN 9636825726

Radnóti, K. (2009). Milyen oktatási és értékelési módszereket alkalmaznak a pedagógusok, https://ofi.oh.gov.hu/milyen-oktatasi-es-ertekelesi-modszereket-alkalmaznak-pedagogusok Retrived: 2020. 06. 14.

Schmuck, R. (2018). Stratégiai szimulációk. Taylor, 10 (1), 130-138.

Soltész, A. (2015). Kockázatelemzési módszerek alkalmazása kocák élettartamának és életteljesítményének vizsgálata során, (PhD dissertation). https://dea.lib.unideb. hu/dea/bitstream/handle/2437/209255/Soltesz_Angela_ertekezes_titkositott. pdf Retrived: 2020. 06. 14.

Szűcs, Z. (2018). Tanítási módszerek fontossága a diákok életében. Paideia, 6(1), 215-228. https://doi.org/10.33034/paideia.2018.6.1.215

Corresponding author:

\section{Viktória Horváthné PeTrás}

Szent István University Kaposvár Campus

Doctoral school for Management and Organizational Science

H-7400 Kaposvár, Guba Sándor utca 40.

e-mail: horvathne.petrasviktoria@gmail.com

(C) Copyright 2020 by the authors.

This is an open access article under the terms and conditions of the

Creative Commons attribution (CC-BY-NC-ND) license 4.0.

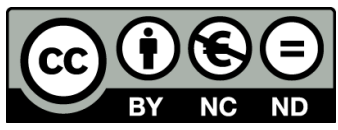

